\title{
ORIGINAL ARTICLE \\ Acetylcholine and an acetylcholinesterase inhibitor neostigmine can aggravate tularemia progress in BALB/C mice
}

\author{
Miroslav POHANKA ${ }^{1}$, Oto PAVLIS 1,2 , Hana SVOBODOVA ${ }^{1}$, Jiri PIKULA ${ }^{3}$ \\ ${ }^{1}$ Faculty of Military Health Sciences, University of Defense, Hradec Kralove, Czech Republic \\ 2 Centre of Biological Defense, Techonin, Czech Republic \\ 3 Faculty of Veterinary Hygiene and Ecology, University of Veterinary and Pharmaceutical Sciences Brno, Czech Republic
}

ITX050112A08 • Received: 14 October 2012 • Revised: 02 February 2012 • Accepted: 10 February 2012

\begin{abstract}
The present experiment was aimed at assessing the application of neostigmine, an acetylcholinesterase (AChE) pseudo-irreversible inhibitor with poor penetration through the hematoencephalitic barrier, and the neurotransmitter acetylcholine (ACh). The experiment was done to evaluate their ability to modulate an infectious disease: tularemia. Mice infected with Franciselle tularensis and exposed to either ACh or neostigmine had a higher mortality and spleen bacterial burden when compared to infected mice exposed to saline solution only. The activated cholinergic anti-inflammatory pathway suppressed pathways necessary for tularemia resolution. Administration of AChE inhibitors to the individuals suffering from tularemia is contra-indicatory. Drugs based on AChE inhibition should be restricted when tularemia or disease with a similar pathogenesis is suspected.
\end{abstract}

KEY WORDS: Francisella tularensis; intracellular pathogen; immunomodulation; cholinergic system; parasympathicus; cholinergic anti-inflammatory pathway

\section{Introduction}

The immunomodulatory role of acetylcholine (ACh) has been considered for a long time (Kaufer et al., 2003). The connection of the nervus vagus to the cholinergic antiinflammatory pathway (CAP) as a specific regulation of the innate immune system by the parasympaticus was first recognized by Tracey and co-workers (Tracey, 2002). CAP was first referd to as reflex-like anti-inflammatory pathway, then the term CAP was introduced. The pathway is based on $\alpha 7$ nicotine acetylcholine receptor (nAChR) on the surface of macrophages and $\mathrm{ACh}$ is released into the blood system from the nervus vagus termination (Tracey, 2009). In the macrophages, the activated CAP inhibits the production of tumor necrosis factor alpha (TNF- $\alpha)$ and other pro-inflammatory intermediates (Wang et al., 2003).

Correspondence address:

RNDr. Miroslav Pohanka, PhD.

Faculty of Military Health Sciences, University of Defense Trebesska 1575, 50001 Hradec Kralove, Czech Republic TEL.: +420720427263; +420973253091 • E-MAIL: pohanka@pmfhk.cz
Francisella tularensis $(\mathrm{Ft})$ is gram-negative bacterium causing the disease known as tularemia. It is considered one of the most important biological warfare agents. Ft is an intracellular pathogen preferably proliferating in macrophage phagosome (Anthony et al., 1991). In the initial phase, interferon gamma (IFN- $\gamma$ ) and TNF- $\alpha$ are necessary for the resolution of tularemia (Fortier et al., 1994). A major role of immune control of tularemia is based on activation of CD4+ and CD8+ T lymphocytes (Fulop et al., 2001, Bosio, 2011). T lymphocyte receptor $\alpha \beta$ knockout mice are sensitive to tularemia and can succumb more easily (Yee et al., 1996).

The present experiment was focused on stimulation of CAP during the progression of tularemia infection. CAP is hypothesized to be able to modify tularemia progression on administration of either $\mathrm{ACh}$ as direct stimulator of $\mathrm{nAChR}$ or of the reversible acetylcholinesterase (AChE) inhibitor neostigmine, which protects endogenous $\mathrm{ACh}$ from splitting by blood AChE. In the final impact, both ACh and neostigmine could over-stimulate CAP localized in blood system without affecting of central nervous system (CNS), due to poor penetration through the bloodbrain barrier (Yamamoto et al., 1995). The achieved data relate to CAP and assess its practical impact. 


\section{Material and methods}

\section{Bacterium}

Francisella tularensis LVS (ATCC 29684) was cultivated on McLeod agar supplemented with bovine hemoglobin and Iso VitaleX (Becton-Dickinson, San Jose, CA, USA) and processed as described previously (Pohanka et al., 2007). Cells were harvested after two days of cultivation and were washed by saline solution using centrifugation $2,000 \times \mathrm{g}$ for 10 minutes. Concentration of fresh cells was estimated using a cell density meter (WPA, Cambridge, UK) and confirmed by a cultivation test.

\section{Animals and tissues processing}

Fiftysix three-month old female BALB/c mice (BioTest, Konarovice, Czech Republic) were divided into 7 groups. Each group contsisted of 8 animals. The mice were kept in an air conditioned room with steady temperature $\left(22 \pm 2^{\circ} \mathrm{C}\right)$ and humidity $(50 \pm 10 \%)$. The artificial light was adjusted at periods from 7 a.m to 7 p.m. The experiment was carried out within the vivarium of the Centre of Biological Defence in Techonin (Czech Republic) and was approved by the central ethical committee (Ministry of Defense, Czech Republic). Food and water was supplied ad libitum during the whole experiment. In the beginning of the experiment, the mice were eight weeks old and weighed on average 20 g. F. tularensis LVS was suspended in saline solution and adjusted to $10^{5}$ colony forming units $(\mathrm{CFU}) / \mathrm{ml}$. Ft LVS as well as neostigmine and ACh (SigmaAldrich; St.Louis, MO, USA) were suspended in saline solution prior to application. The groups were as follows:

- $100 \mu \mathrm{l}$ of Ft suspension; $100 \mu \mathrm{l}$ of saline solution

- $100 \mu \mathrm{l}$ of Ft suspension; $100 \mu \mathrm{l}$ of neostigmine $40 \mathrm{mg} / \mathrm{l}$, dose $0.2 \mathrm{mg} / \mathrm{kg}$ body weight

- $\quad 100 \mu \mathrm{l}$ of Ft suspension; $100 \mu \mathrm{l}$ of acetylcholine $60 \mathrm{mg} / \mathrm{l}$, dose $0.3 \mathrm{mg} / \mathrm{kg}$ body weight

- $\quad 100 \mu \mathrm{l}$ saline solution; $100 \mu \mathrm{l}$ of neostigmine $40 \mathrm{mg} / \mathrm{l}$, dose $0.2 \mathrm{mg} / \mathrm{kg}$ body weight

- $\quad 100 \mu \mathrm{l}$ of saline solution; $100 \mu \mathrm{l}$ of acetylcholine $60 \mathrm{mg} / \mathrm{l}$, dose $0.3 \mathrm{mg} / \mathrm{kg}$ body weight

- $\quad 100 \mu \mathrm{l}$ of saline solution for two administrations.

The solutions were administered subcutaneously in the area of the pelvic limb. Neostigmine, ACh and saline solution were applied one hour after Ft suspension. Tularemia was confirmed in all infected animals by the appearance of typical disease signs.

Table 1. Bacterial burden in spleen of mice exposed to tularemia $(\mathrm{Ft})$ tularemia with neostigmine ( $\mathrm{Ft}+\mathrm{neo})$, and tularemia with acetylcholine $(\mathrm{Ft}+\mathrm{ACh})$

\begin{tabular}{ccc|}
\hline \multicolumn{3}{c}{ Bacterial burden \pm S.D. (CFU) } \\
$\mathrm{Ft}$ & $\mathrm{Ft}+$ neo & $\mathrm{Ft}+\mathrm{ACh}$ \\
\hline$(5.50 \pm 3.83) \times 10^{4}$ & $(1.38 \pm 0.52) \times 10^{5 * *}$ & $(3.95 \pm 1.33) \times 10^{5 * *}$ \\
\hline
\end{tabular}

Significance at $p=0.01$ against the first (Ft) group is indicated by the two asterisks.
After five days, mice were sacrificed under $\mathrm{CO}_{2}$ anesthesia. Spleens were collected and homogenized for cultivation in order to estimate the bacterial burden. The mortality experiment was carried out in the same way as given above. The dose of Ft was $100 \mu \mathrm{l} 10^{8} \mathrm{CFU} / \mathrm{ml}$. All other parameters were unchanged.

\section{Statistical analysis}

Origin 8 (OriginLab Corporation, Northampton, MA, USA) was used for data processing throughout the experiments and performed for descriptive as well as inferential statistics. Significance of differences between the groups tested was estimated using one-way analysis of variance with Tukey's test. The significance was recalculated for two probability levels $p=0.05$ as well as $p=0.01$ for the group size $\mathrm{n}=8$.

\section{Results}

The bacterial burden of the spleen was assayed immediately after the animals had been sacrificed. In compliance with expectations, the animals that were not infected with tularemia had no positive cultivation proof. The animals infected with tularemia had on average content $5.50 \times 10^{4}$ Ft CFU per spleen. Animals infected and simultaneously exposed to ACh or neostigmine had significantly $(p \leq 0.01)$ increased Ft levels. The spleens from animals exposed to neostigmine had on average of $1.38 \times 10^{5} \mathrm{CFU}$. The highest Ft content was found after ACh administration: $3.95 \times 10^{5}$ CFU. The data are shown in Table 1.

The mortality test compared the impact of the compounds tested on survival of tularemia infected animals (Figure 1) No mortality was observed in mice treated only with saline solution (control), ACh, or neostigmine. Infection with $\mathrm{Ft}$ caused $40 \%$ mortality. Co-application of ACh resulted in 50\% mortality (comparison to Ft group:

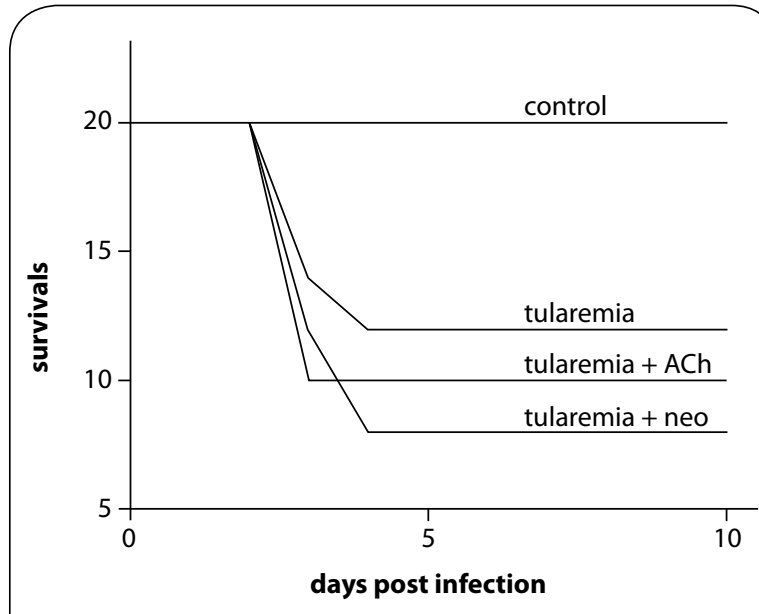

Figure 1. mortality after tularemia infection and acetylcholine (ACh) or neostigmine (neo) administration. 
Chi Square 0.833; $\mathrm{df}=1 ; p=0.361$ ) and of neostigmine in $60 \%$ mortality (Chi Square $3.33 ; \mathrm{df}=1 ; p=0.067$ ). The observed mortality occurred from the third to fourth day post infection. No mortality occurred before and after that time.

\section{Discussion}

The multiple factors investigated during the experiments pointed to some interesting processes accompanying tularemia and/or CAP stimulation. The pyroptosis cell-death bears signs of necrosis and pro-inflammatory reaction (Bergbaken \& Cookson, 2009; Kepp et al., 2010). The stress markers arising during tularemia were also described in previous experiments (Pohanka et al., 2009; Bandouchova et al., 2009a). Generally, activation of CAP is expected to ameliorate inflammation induced pathogeneses as the direct impact on tissues can be diminished. On the other hand, activation of CAP can reduce the ability of the immune system to fight the pathogen.

Both ACh and neostigmine were administered in safe doses. The dose of ACh corrresponded to the mammalian physiological level (Fujii et al., 1997). The neostigmine dose was correlated to the common medium amount per kilogram used in human medicine (Kopman and Eikermann, 2009). The most significant impact of neostigmine as well as of ACh was recognized in the bacterial burden and tularemia induced mortality. The bacterial burden was significantly increased in the spleen both after neostigmine and ACh administration. The bacterial burden corresponds to the organism's sensitivity to tularemia (Bandouchova et al., 2009b) and an elevated bacterial burden should deductively correspond to higher mortality. In full agreement with the hypothesis, increased mortality was found after ACh as well as neostigmine administration.

CAP is linked to suppression of inflammation. When it is stimulated, the inflammation signaled by $C$-reactive protein and TNF- $\alpha$ is decreased (Jae et al., 2009). The hypothesis set in the experiment was based on the question whether administration of compounds directly stimulating $\mathrm{nAChR}$, Ach in the presaent study, or compounds inhibiting $\mathrm{AChE}$, represented by neostigmine, and thus elevating endogenous blood ACh level, could modulate tularemia progression. Neostigmine was chosen on purpose for the fact that it does not cross the blood-brain barrier (Yamamoto et al., 1995). The effect was not clearly comprehensible as parasympathetic rather than sympathetic response should be expected due to acetylcholine-evoked relaxation (Sotnikova et al., 2009). The drug for Alzheimer's disease treatment, Donepazil, has the same effect as it reduces stress and increases the ACh level even during exposition to bacterial liopolysaccharide (Tyagi et al., 2010). On the other hand, the recognized oxidative stress after ACh administration could be triggered by another mechanism, not involved in ACh regulative function.

Stimulation of CAP and suppression of related cytokines production is well expected (Rosas-Ballina et al., 2009). The primary question was to assess whether tularemia can be influenced by stimulation of CAP. The response was positive. Mortality and bacterial burden confirmed that stimulation of CAP in the first stage of tularemia is a negative process as the activated CAP does not allow simple activation of macrophages. The explanation is in full compliance with experiments of other authors. IL-1 $\beta$ deficient mice have a lower probability to survive tularemia (Fernandes-Alnemri et al., 2010). Cytokines such as IFN- $\gamma$ and TNF- $\alpha$ as well as $\mathrm{T}_{\mathrm{H}_{1}}{ }^{-}$ lymphocytes are necessary to resolve the disease (Elkins et al., 2009; Lin et al., 2009). On the other hand, Ft needs to survive in macrophages and proliferate there in the phagosome (Bell et al., 2010). Thus activated CAP could suppress pathways necessary for tularemia resolution. Administration of AChE inhibitors to individuals suffering from tularemia is contraindicatory. Drugs based on AChE should be restricted when tularemia is suspected. On the contraty, inhibition of CAP can be hypothesized as an appropriate approach since a positive effect can be expected.

\section{Conclusions}

CAP seems to be a relevant regulatory tool influencing the immune system. Unsubstantial stimulation of CAP can deteriorate proliferation of the intracellular pathogen F. tularensis. Drugs based on AChE inhibition or nAChR stimulation are not applicable to individuals suspected to suffer from tularemia. Their impact is significantly contraindicatory. On the other hand, blockade of the nAChR is hypothesized as a suitable tool to be assessed in further experiments regarding tularemia treatment.

\section{Acknowledgement}

The Faculty of Military Health Sciences, University of Defense is gratefully acknowledged for the specific research project "Assay of biochemical and pharmacokinetic parameters of selected inhibitors of acetylcholinesterase" and the Ministry of Defence of the Czech Republic is gratefully acknowledged for the project No. OVUOFVZ200802 and the Ministry of Education, Youth and Sport of Czech Republic is gratefully acknowledged for the project No. LH11023.

\section{REFERENCES}

Anthony LSD, Burke RD and Nano FE. (1991). Growth of Francisella spp. in rodent macrophages. Infect Immun 59: 3291-3296.

Bandouchova H, Sedlackova J, Pohanka M, Novotny L, Hubalek M, Treml F, Vitula F and Pikula J. (2009a). Tularemia induces different biochemical responses in BALB/c mice and common voles. BMC Infect Dis 9: 101.

Bandouchova H, Sedlackova J, Hubalek M, Pohanka M, Peckova L, Treml F, Vitula F and Pikula J. (2009b). Susceptibility of selected murine and microtine species to infection by a wild strain of Francisella tularensis subsp. holarctica. Vet Med (Czech) 54: 64-74. 
Bell BL, Mohapatra NP and Gunn JS. (2010). Regulation of virulence gene transcripts by the Francisella novicida orphan response regulator PmrA: role of phosphorylation and evidence of MGIA/SspA interaction. Infect Immun 78: 2189-2198.

Bergsbaken T and Cookson BT. (2009). Innate immune response during Yersinia infection: critical modulation of cell death mechanisms through phagocyte activation. J Leukoc Biol 86: 1153-1158.

Bosio CM. (2011). The subversion of the immune system by Francisella tularensis. Frontiers in Microbiology, www.frontiersin.org, volume 2, article 9 doi: 10.3389/frmicb.2011.00009

Elkins KL, Colombini SM, Krieg AM and De Pascalis R. (2009). NK cells activated in vivo by bacterial DNA control the intracellular growth of Francisella tularensis LVS. Microbes Infect 11: 49-56.

Fernandes-Alnemri T, Yu JW, Juliana C, Solorzano L, Kang S, Wu J, Datta P, MCCormick M, Huang L, McDermott E, Eisenlohr L, Landel CP and Alnemri ES. (2010). The AIM2 inflammmasome is critical for innate immunity to Francisella tularensis. Nat Immunol 11: 385-393.

Fortier AH, Green SJ, Polsinelli T, Jones TR, Crawford RM, Leiby DA, Elkins KL, Meltzer MS and Nacy CA. (1994). Life and death of an intracellular pathogen: Francisella tularensis and the macrophage. Immunol Ser 60: 349-361.

Fujii T, Mori Y, Tominaka T, Hayasaka I and Kawashima K. (1997). Maintenance of constant blood acetylcholine content bofore and after feeding in young chimpanzees. Neurosci Lett 227: 21-24.

Fulop M, Mastoeni P, Green M and Titball RW. (2001). Role of antibody to lipopolysacharide in protection against low - and high - virulence strains of $F$. tularensis. Vaccine 19: 4465-4472.

Jae SY, Heffernan KS, Yoon ES, Lee MK, Fernhall B and Park WH. (2009). The inverse assoctiation between cardiorespiratory fitness and C-reative protein is mediated by autonomic function: a possible role of the cholinergic antiinflammatory pathway. Mol Med 15: 291-296.

Kaufer D, Friedman A, Seldman S and Soreq H. (2003). Acute stress facilitates long-lasting changes in cholinergic gene expression. Nature 393: 373-377.

Kepp O, Galluzzi L, Zitvogel L and Kroemer G. (2010). Pyroptosis - a cell death modality of its kind. Eur J Immunol 40: 627-630.

Kopman AF and Eikermann M. (2009). Antagonism of non-depolarising neuromuscular block: current practice. Anaesthesia 64: 22-30.
Lin Y, Ritchea S, Logar A, Slight S, Messmer M, Rangel-Moreno J, Guglani L, Alcorn JF, Strawbridge H, Park SM, Onishi R, Nyugen N, Walter MJ, Pociask D, Randall TD, Gaffen SL, Iwakura Y, Kolls JK and Khader SA. (2009). Interleukin-17 is required for Thelper 1 cell immunity and host resistance to the intracellular pathogen Francisella tularensis. Immunity 31: 799-810.

Lykkesfeldt J. (2007). Malondialdehyde as biomarker of oxidative damage to lipids caused by smoking. Clin Chim Acta 380: 50-58.

Pohanka M, Pavlis O and Skladal P. (2007). Diagnosis of tularemia using piezoelectric biosensor technology. Talanta 71: 981-985.

Pohanka M, Bandouchova H, Novotny L, Pavlis O, Treml F, Sedlackova J and Pikula J. (2009). Assessment of low-molecular-weight antioxidants in Francisella tularenis infected hosts: comparison of two rodents with different susceptibility to tularemia. Neuro Endocrinol Lett 30 (suppl. 1): 186-191.

Rosas-Ballina M, Goldstein RS, Gallowitsch-Puerta M, Yang L, Valdes-Ferrer SI, Patel NB, Chavan S, Al-Abed Y, Yang H and Tracey KJ. (2009). The selective alpha7 agonist GTS-21 attenuates cytokine production in human whole blood and human monocytes activated by ligands for TLR2, TLR3, TLR4, TLR9, and RAGE. Mol Med 15: 195-202.

Sotnikova R, Ponist S, Navarova J, Mihalova D, Tomekova V, Strosova M and Bauerova K. (2009). Effects of sesame oil in the model of adjuvant arthritis. Neuro Endocrinol Lett 30 (suppl 1): 22-24.

Tracey KJ. (2002). The inflammatory reflex. Nature 420: 853-859.

Tracey KJ. (2009). Reflex control of immunity. Natur Rev Immunol 9: 418-428.

Tyagi E, Agrawal R, Nath C and Shukla R. (2010). Cholinergic protection via alpha7 nicotinic acetylcholine receptors and PI3K-Akt pathway in LPS-induced neuroinflammation. Neurochem Int 56: 135-142.

Wang H, Yu M, Ochani M, Amella CA, Tanovic M, Susaria S, Li JH, Wang H, Yang H, Ulloa L, Al-Abed Y, Czura CJ and Tracey KJ. (2003). Nicotinic acetylcholine receptor alpha7 subunit is an essential regulator of inflammation. Nature 421: 384-388.

Yamamoto K, Sawada Y and Iga T. (1995). Comparative pharmacokinetics of four cholinesterase inhibitors in rats. Biol Pharm Bull 18: 1292-1295.

Yee D, Rhinebbart-Jones TR and Elkins L. (1996). Loss of either CD4+ or DC8+ $T$ cells does not affect the magnitude of protective immunity to an intracellular pathogen Francisella tularensis strain LVS. J Immunol 157: 5042-5048. 